\title{
Detection of femtomolar level osteosarcoma- related gene via a chronocoulometric DNA biosensor based on nanostructure gold electrode
}

This article was published in the following Dove Press journal:

International Journal of Nanomedicine

31 January 2012

Number of times this article has been viewed

\author{
Ailin Liu ${ }^{1,2, *}$ \\ Xiongwei $\mathrm{Xu}^{4}$ \\ Zhouliang Sun ${ }^{5}$ \\ jinyuan Chen ${ }^{1,2}$ \\ Kun Wang ${ }^{1,5}$ \\ Qicai Liu ${ }^{6}$ \\ Xinhua $\operatorname{Lin}^{1,2}$ \\ Jianhua $\operatorname{Lin}^{3,7}$
}

Guangxian Zhong ${ }^{1,3,7, *}$

'Department of Pharmaceutical Analysis, Faculty of Pharmacy, Fujian Medical University, Fuzhou, ${ }^{2} \mathrm{Nano}$ Biomedical Technology Research Center, Fujian Medical University, Fuzhou, ${ }^{3}$ Department of Orthopedics, ${ }^{4}$ Department of Pharmacy, the First Affiliated Hospital of Fujian Medical University, Fuzhou, ${ }^{5}$ Department of Pharmacy, the First Affiliated Hospital of Xiamen University, Xiamen,

${ }^{6}$ Department of Clinical Laboratory, the First Affiliated Hospital of Fujian Medical University, Fuzhou, ${ }^{7}$ Fujian Institute of Orthopedics, the First Affiliated Hospital of Fujian Medical University, Fuzhou, People's Republic of China

*These authors contributed equally to this study

Correspondence: Xinhua Lin; Jianhua Lin Tel +8659122862016

Fax +86 59I 22862016

Email xhl1963@sina.com (XH Lin)

jianhual@I26.com (JH Lin)

\begin{abstract}
In this paper, a sensitive chronocoulometric deoxyribonucleic acid (DNA) biosensor based on a nanostructure gold electrode was fabricated for detection of the femtomolar level survivin gene which was correlated with osteosarcoma by using hexaamine-ruthenium III complexes, $\left[\mathrm{Ru}\left(\mathrm{NH}_{3}\right)_{6}\right]^{3+}$, as the electrochemical indicator. The effect of different frequencies on the real surface area of the nanostructure gold electrode obtained by repetitive square-wave oxidation reduction cycle was investigated. At the optimal frequency of $8000 \mathrm{~Hz}$, the real surface of the developed nanostructure gold electrode was about 42.5 times compared with that of the bare planar gold electrode. The capture probe DNA was immobilized on the nanostructure gold electrode and hybridized with target DNA. Electrochemical signals of hexaamine-ruthenium III bound to the anionic phosphate of DNA strands via electrostatic interactions were measured by chronocoulometry before and after hybridization. The increase of the charges of hexaamineruthenium III was observed upon hybridization of the probe with target DNA. Results indicate that this DNA biosensor could detect the femtomole (fM) concentration of the DNA target quantitatively in the range of $50 \mathrm{fM}$ to $250 \mathrm{fM}$; the detection limit of this DNA biosensor was $5.6 \mathrm{fM}$ (signal to noise $=3$ ). This new biosensor exhibits excellent sensitivity and selectivity and has been used for an assay of polymerase chain reaction (PCR) with a satisfactory result. Keywords: chronocoulometric DNA biosensor, survivin gene, hexaamine-ruthenium III complexes, nanostructure gold electrode, femtomolar level
\end{abstract}

\section{Introduction}

Osteosarcoma is the most common malignant bone tumor and occurs most frequently during adolescence. Current treatment protocols for osteosarcoma include radical surgery and neoadjuvant chemotherapy, which has increased survival rates from $20 \%$ to $75 \%{ }^{1}$ Clinically, prognosis is determined postoperatively by response to chemotherapy, tumor size, and wide surgical margin, which in the past has been the only useful prognostic parameter. In recent years, some studies have demonstrated that survivin is correlated with osteosarcoma and could be used as a molecular marker for prognosis of osteosarcoma. ${ }^{2,3}$

Survivin is a member of the inhibitor of apoptosis protein (IAP) family. It is characterized by the presence of a single baculoviral inhibitor of apoptosis protein repeat and lacks a carboxyl terminal "really interesting new gene" finger domain in its protein structure. ${ }^{4-6}$ The survivin protein functions to inhibit caspase activation, thereby leading to negative regulation to apoptosis or programmed cell death. ${ }^{7}$ It is considered to be an important factor that provides potent resistance against chemotherapeutic drugs. ${ }^{8}$ Several studies have demonstrated resistance of survivin-expressing cells to anticancer 
drug-induced apoptosis..$^{9,10}$ Moreover, the survivin protein is expressed highly in fetal tissue and most human tumors such as gastric cancer, breast cancer, lung cancer, colorectal cancer, pancreatic cancer, urinary bladder cancer, soft tissue cancer, neuroblastoma, and osteosarcoma, but is completely absent in normal differentiated cells. ${ }^{11}$ Therefore, survivin could be used as an ideal biomarker for cancer prognosis and may also offer therapeutic alternatives for cancer treatment. ${ }^{12,13}$ In recent years, monitoring methods of survivin gene include chromosome analysis, ${ }^{14}$ fluorescence in situ hybridization, ${ }^{15}$ flow cytometry, ${ }^{16}$ and real-time quantitative reverse transcription polymerase chain reaction (PCR). ${ }^{17}$ But there are some limitations to these methods, such as time consuming, poor precision, and expensiveness. Therefore, it is very important to develop a new effective method to detect the survivin gene.

Electrochemical biosensor, as a monitoring technique, is widely considered to be promising for diagnosis of genetic diseases and other biological analyses due to its rapid and sensitive response as well as simple and convenient operation. ${ }^{18-21}$ Recent developments in nanomaterials and nanotechnologies have greatly improved the sensitivity and selectivity of electrochemical biosensors. ${ }^{22,23}$ Chang et al fabricated an ultrasensitive electrochemical nucleic acid biosensor using the conducting polyaniline nanotube array as the signal enhancement element, and could readily detect the target oligonucleotide at a concentration as low as 1.0 femtomole (fM). ${ }^{24}$ Zhang et al developed a chronocoulometric deoxyribonucleic acid (DNA) biosensor based on nanoparticle-mediated amplification and nanoscale control of DNA assembly at electrodes. ${ }^{25}$ This DNA sensor could detect as low as femtomolar DNA targets and exhibited excellent selectivity against even a single-base mismatch. The introduction of nanomaterial could efficiently increase the electrode surface area and enlarge the DNA immobilization amount. On the other hand, some dependent reagents in the preparation of nanomaterial produced a negative impact on the fabricated biosensor. ${ }^{26,27}$ Moreover, particle aggregation often existed in gold nanoparticles.

To overcome the drawbacks mentioned above, high surface area nanostructure gold (NSG) has recently attracted increasing attention due to its fascinating properties, such as superior conductivity, large surface area, high stability, and biocompatibility. Several methods, such as electrochemical deposition, ${ }^{28,29}$ electrochemical erosion, ${ }^{30}$ electrochemical oxidation/chemical reduction processes, ${ }^{31}$ chemical dealloying of alloys, ${ }^{32-34}$ electrochemical alloying/dealloying, ${ }^{35-37}$ and template synthesis, ${ }^{38-40}$ were reported to be used to prepare nanostructure materials. However, the catalytic activities of NSG electrodes prepared by electrochemical erosion and electrochemical oxidation/chemical reduction are low. The chemical dealloying of alloys method requires complicated advance processes to prepare the gold alloys. The preparation process of the template synthesis method is too complicated. Finally, direct electrode position from chloroauric acid solution is a rapid and easy way to obtain gold nanofilm, but the prepared gold nanofilm is incompact with a comparatively small quantity of nanoparticles.

A straightforward, rapid and "green" approach for the fabrication of nanostructure material was proposed by the repetitive square-wave oxidation reduction cycle (SWORC). Bilmes et al prepared roughened platinum by using repetitive SWORC, which was used for the enhancement of surfaceenhanced Raman scattering. ${ }^{41}$ Gamero et al developed a biosensor for the detection of lactate using a nanostructured rough gold surface prepared with repetitive SWORC as transducer. ${ }^{42}$ Recently, the authors fabricated an electrochemical DNA biosensor based on this NSG electrode for detection of promyelocytic leukemia/retinoic acid receptor $\alpha$ fusion gene by using methylene blue as electroactive indicator. ${ }^{43}$

In this work, a chronocoulometric DNA based on an NSG electrode was fabricated for detection of the survivin gene which was correlated with osteosarcoma. The captured DNA was self-assembled onto a NSG electrode surface via a gold-sulfur bond, and then hybridized with target DNA. Cyclic voltammetry and chronocoulometry was employed to monitor variation before and after hybridization by using hexaamine-ruthenium III complexes, $\left[\mathrm{Ru}\left(\mathrm{NH}_{3}\right)_{6}\right]^{3+}$ (RuHex), as an electroactive indicator. RuHex, as an electroactive signaling molecule, binds to the anionic phosphate of DNA strands through electrostatic interaction and is free of any duplex intercalation. ${ }^{44}$ As a result, the redox charge of RuHex is a direct function of the amounts of DNA strands localized at electrode surfaces. ${ }^{44}$ This new method is able to detect $5.6 \mathrm{fM}$ synthetic target DNA and demonstrates its excellent differentiation ability for single-base mismatch and complementary (double-stranded DNA; dsDNA) after hybridization.

\section{Material and methods Chemicals and materials}

Ethylenediaminetetraacetic acid, mercaptohexanol (MCH), and RuHex were purchased from Sigma-Aldrich Corporation (St Louis, MO). Tris(2-carboxyethyl)phosphine hydrochloride was purchased from Shanghai Sangon Biological Engineering Technology and Services Co, Ltd (Shanghai, China). Potassium ferricyanide and potassium ferrocyanide were 
obtained from Sinopharm Chemical Reagent Co, Ltd (Shanghai, China). All other chemicals were of analytical grade and used without further purification.

All synthetic oligonucleotides designed according to survivin messenger ribonucleic acid were purchased from Takara Biotechnology Co, Ltd (Dalian, China). Their base sequences were as follows: immobilized probe (22-base sequence S1) 5'-hydrosulfuryl (HS)-TTG GAG GGC TGC GCC TGC ACC C-3'; target DNA (22-base sequence S2) 5'-GGG TGC AGG CGC AGC CCT CCA A-3'; singlemismatched DNA (22-base sequence S3) 5'-GGG TGC AGC CGC AGC CCT CCA A-3'; noncomplementary DNA (22-base sequence S4) 5'-CGG GGA GGC AGC CAT TGA GAC C-3'. Stock solutions of RuHex (1.0 mM) were prepared with deionized water. The buffer solutions employed in this study were as follows: DNA immobilization buffer was $10 \mathrm{mM}$ tris(hydroxymethyl)aminomethane-hydrochloride (tris- $\mathrm{HCl}$ ), $1.0 \mathrm{mM}$ ethylenediaminetetraacetic acid, $10 \mathrm{mM}$ tris(2-carboxyethyl)phosphine hydrochloride ( $\mathrm{pH} 7.4)$, and 1.0 M sodium chloride; hybridization buffer was $1 \mathrm{M}$ sodium chloride and $10 \mathrm{mM}$ phosphate buffered saline ( $\mathrm{pH} 7.4)$; buffer for both electrochemistry and electrode washing was $10 \mathrm{mM}$ tris- $\mathrm{HCl}$ solution ( $\mathrm{pH}$ 7.4). All solutions were prepared with Milli- $\mathrm{Q}^{\mathrm{TM}}$ water (18.2 $\mathrm{M} \Omega \mathrm{cm}$ resistivity) from a Millipore system (Millipore Corporation, Billerica, MA).

\section{Apparatus}

All electrochemical measurements were performed on a CHI760D electrochemical workstation (CH Instruments, Inc, Austin, TX). Electrochemical experiments were carried out with a conventional three-electrode system comprising a gold working electrode, a platinum wire auxiliary electrode, and a silver/silver chloride (with saturated potassium chloride) reference electrode. All potentials herein were referred to this reference electrode. Cyclic voltammetry was carried out at a scan rate of $50 \mathrm{mV} / \mathrm{second}$ and chronocoulometry at a pulse width of 250 milliseconds. Scanning electron microscopic (SEM) images were obtained using an XL-30E scanning electron microscopy (Philips, Amsterdam, the Netherlands). The electrolyte buffer was thoroughly purged with nitrogen before experiments.

\section{Preparation of NSG electrode}

The detailed procedure used to prepare nanostructure has been described previously except for the different frequency in SWORC fabrication process for real surface area increase. ${ }^{43}$ The improved NSG electrode procedures are briefly described here. The bare planar gold electrode surface ( $2 \mathrm{~mm}$ in diameter) was freshly polished prior to use with 1.0, 0.3, and $0.05 \mu \mathrm{m}$ alumina powder, respectively, and then cleaned ultrasonically sequentially in ethanol and water for 5 minutes. After electrochemically cleaning in fresh $0.5 \mathrm{M}$ sulfuric acid solution to remove any possible impurities on the surface, ${ }^{45}$ the gold electrode was then subjected to electrochemical pretreatment by two consecutive stages. Firstly, a relatively thick hydrous gold oxide layer was accumulated on the gold electrode immersed in $0.5 \mathrm{M}$ sulfuric acid by using repetitive square-wave potential between $-0.8 \mathrm{~V}$ and $2.5 \mathrm{~V}$ (versus silver/silver chloride electrode) at different frequencies for a time of 5 minutes. In the following stage, the potential was held at $-0.8 \mathrm{~V}$ until complete electroreduction of the hydrous gold oxide layer was accomplished..$^{41}$ The resulting NSG electrode was sonicated in deionized water for 1 minute and cycled at $0.1 \mathrm{~V} /$ second between $-0.35 \mathrm{~V}$ and $1.5 \mathrm{~V}$ in $0.5 \mathrm{M}$ sulfuric acid solution to clean the surface of the electrode, and check variations in the electroadsorption charge of the $\mathrm{O}$ adatoms between the rough gold electrode and planar gold electrode.

\section{DNA self-assembly and hybridization at NSG electrode}

The cleaned nanostructure electrode was immersed into an immobilization buffer containing $10 \mu \mathrm{M}$ capture probe modified with thiolate for 2 hours at room temperature to form a self-assembled monolayer. The single-stranded DNA (ssDNA)-modified electrode was then treated with $1.0 \mathrm{mM} \mathrm{MCH}$ for 1 hour to obtain a well-aligned ssDNA/ $\mathrm{MCH}$-modified electrode, ${ }^{46}$ followed by thoroughly washing with deionized water to remove unspecific adsorbed DNA probe. The ssDNA/MCH-modified electrode was immersed in phosphate buffered saline solution containing synthetic targets or PCR real samples for 30 minutes at $45^{\circ} \mathrm{C}$ to form dsDNA. ${ }^{47}$ The PCR real samples should be heated at $95^{\circ} \mathrm{C}$ for 10 minutes and cooled in an ice bath before use. After that, dsDNA-modified electrodes were washed with deionized water and immersed in $0.1 \%$ sodium dodecyl sulfate phosphate buffer ( $\mathrm{pH} 7.40$ ) to remove unbound oligonucleotides before RuHex accumulation.

\section{DNA hybridization detection with an electrochemical indicator of RuHex}

The probe DNA or hybridized electrodes were firstly immersed into $10 \mathrm{mM}$ tris- $\mathrm{HCl}$ solutions ( $\mathrm{pH}$ 7.4) containing $20 \mu \mathrm{M}$ RuHex for 30 minutes, and then the cyclic voltammograms and chronocoulometry were recorded in blank $10 \mathrm{mM}$ tris- $\mathrm{HCl}$ solutions. 


\section{Results and discussion Preparation of NSG electrode}

A schematic representation of the novel sensor fabrication procedure is shown in Figure 1. The NSG electrode was firstly prepared by a repetitive SWORC strategy and then used as the substrate for DNA immobilization and hybridization. In order to examine the effect of frequency on real surface area of the NSG electrode, different frequency was applied in the preparation of the NSG electrode. As shown in Figure 2A and $\mathrm{B}$, the real surface area increased with increasing frequency and reached maximum value when the cleaned planar gold electrode was immersed in $0.5 \mathrm{M}$ sulfuric acid by using repetitive square-wave potential between $-0.8 \mathrm{~V}$ and $2.5 \mathrm{~V}$ (versus silver/silver chloride reference electrode) at $8000 \mathrm{~Hz}$ for 5 minutes. The maximum real surface area was about 42.5 times compared with that of the planar gold electrode by assuming that the reduction of the monolayer of gold oxide requires $386 \mu \mathrm{Ccm}^{-2}$. SEM images of the same gold electrode before and after pretreatment of SWORC at $8000 \mathrm{~Hz}$ for 5 minutes are shown in Figure 2C and D. As shown in Figure 2D, the NSG electrode surface was divided into two layers. The bottom layer was a brain-like nanostructure, which is the same as one reported in previous work. ${ }^{43}$ The upper layer was a cotton-wool-like nanostructure. The real surface of the NSG electrode prepared by this strategy was larger than those of direct electrochemical deposition gold strategy, ${ }^{29}$ dealloying strategy from silver/ gold alloys, ${ }^{48}$ three-dimensionally ordered macroporous template strategy, ${ }^{39}$ and hydrogen bubble dynamic template synthesis strategy.

\section{Electrochemical characteristics of the modified electrode surface}

All electrochemical measurements were performed in $10 \mathrm{mM}$ iron-hexacyano complexes, $\left[\mathrm{Fe}(\mathrm{CN})_{6}\right]^{3-/ 4-}$, and $0.1 \mathrm{M}$ potassium chloride solution at a scan rate of $100 \mathrm{mV} / \mathrm{second}$. Electrochemical impedance spectroscopy was chosen as a marker to investigate the changes of the electrode behavior after each assembly step. The impedance spectra included a semicircle portion at higher frequencies corresponding to the electrotransfer-limited process and a linear portion at lower frequencies representing the diffusion-limited process. The semicircle diameter equaled the electrotransfer resistance $\left(\mathrm{R}_{\mathrm{et}}\right)$, which dominated the electron transfer kinetics of the redox probe at the electrode interface. Figure 3 shows the Faradaic impedance spectra observed upon the stepwise modification process with the NSG electrode (Figure 3A) and planar gold electrode (Figure 3B) at a potential of $0.2 \mathrm{~V}$ (versus silver/silver chloride) in the frequency range of $0.05-10^{5} \mathrm{~Hz}$. Inset shows the electrical equivalent circuit. For the bare NSG electrode, the value of $\mathrm{R}_{\mathrm{et}}$ was $0 \Omega$, demonstrating high conductivity due to its nanoporous architecture. When the probe was self-assembled onto the electrode surface, $\mathrm{R}_{\mathrm{et}}$ increased from $0 \Omega$ to $1862 \Omega$ due to the electrostatic repulsion between the negativelycharged probe and the negatively-charged redox probe
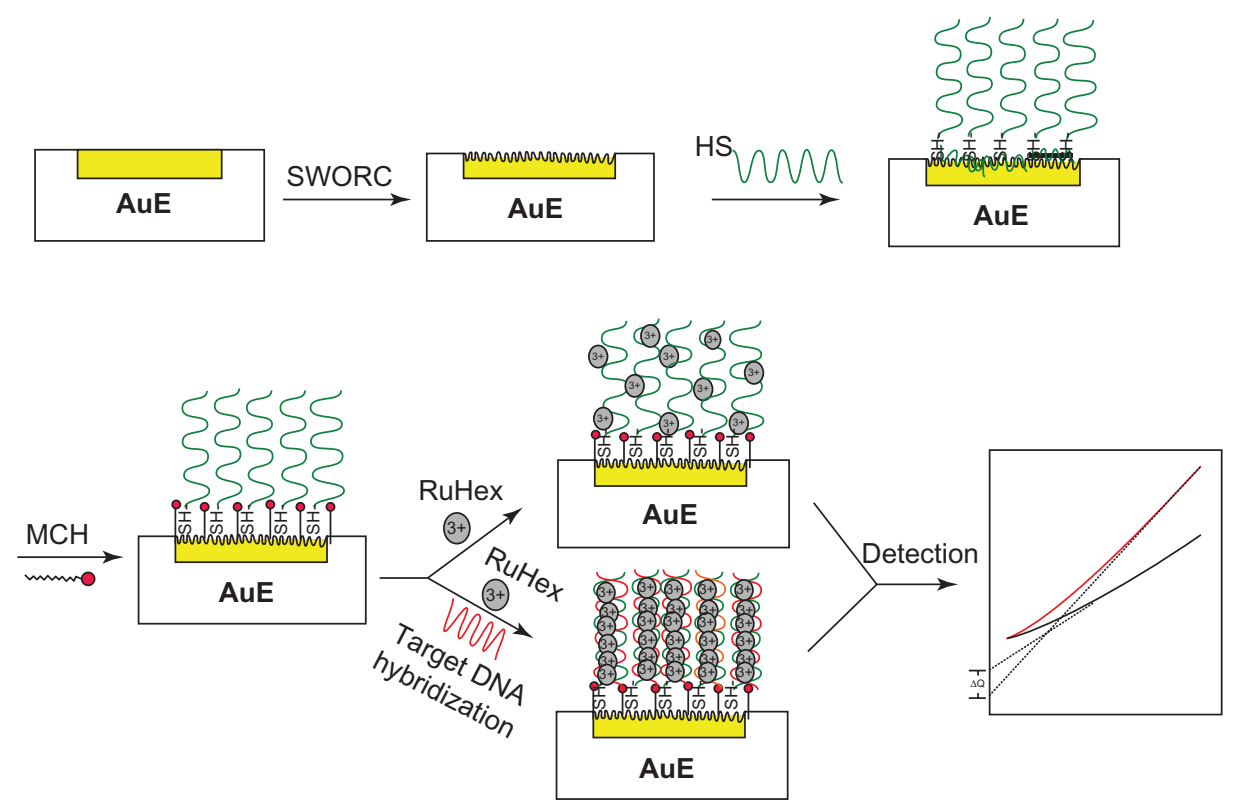

Figure I Schematic representation of the fabrication procedure of deoxyribonucleic acid biosensor based on nanostructure gold electrode.

Abbreviations: AuE, gold electrode; DNA, deoxyribonucleic acid; HS, hydrosulfuryl; MCH, mercaptohexanol; RuHex, hexaamine-ruthenium III; SWORC, square-wave oxidation reduction cycle. 

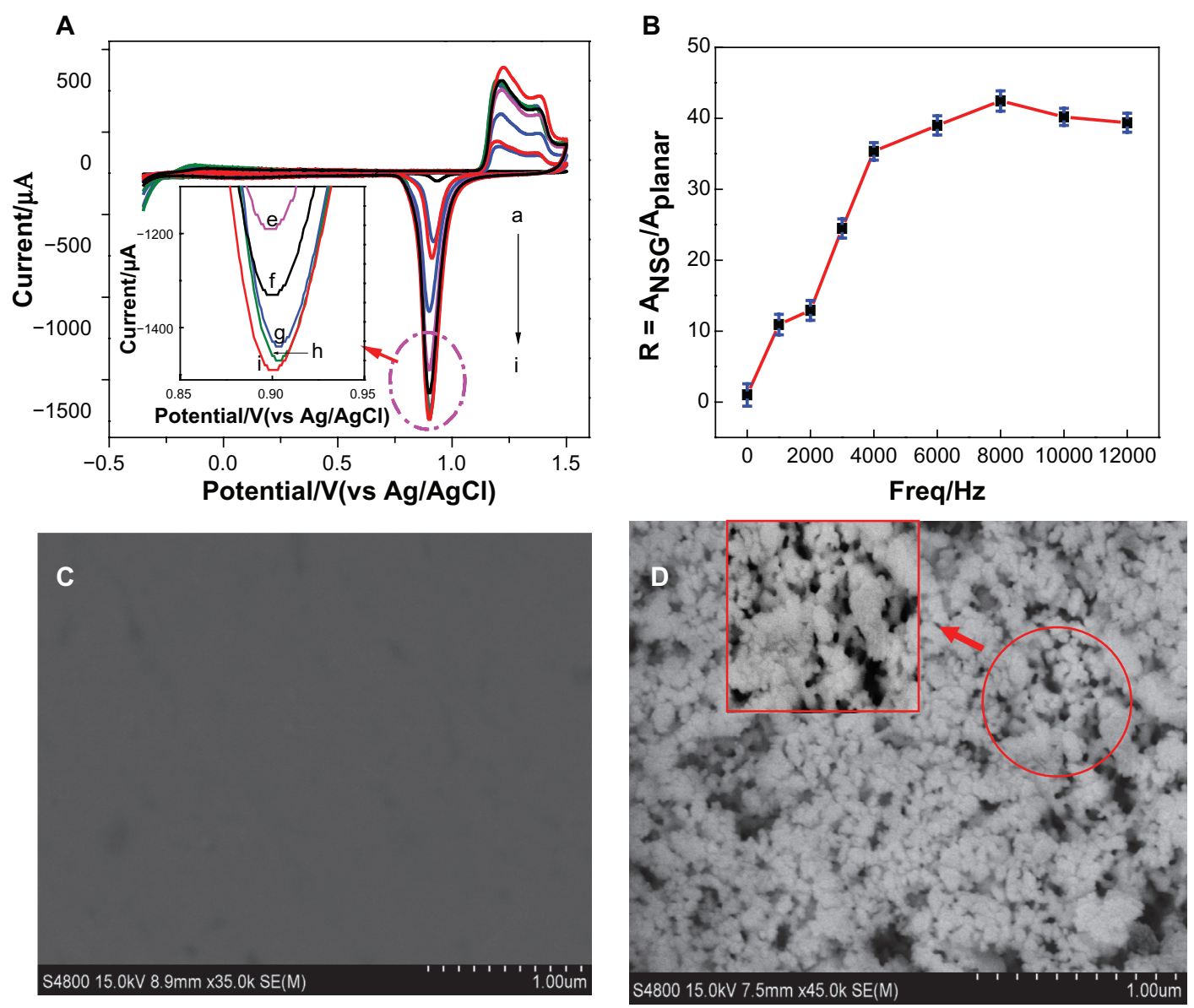

Figure 2 (A) Cyclic voltammograms of nanostructure gold electrode with different frequency in a solution of $0.5 \mathrm{M}$ sulfuric acid at a scan rate of $\mathrm{I} 00 \mathrm{mV} / \mathrm{second}$. (a) $0 \mathrm{~Hz}$, (b) $1000 \mathrm{~Hz}$, (c) $2000 \mathrm{~Hz}$, (d) $3000 \mathrm{~Hz}$, (e) $4000 \mathrm{~Hz}$, (f) $6000 \mathrm{~Hz}$, (g) I2,000 Hz, (h) I0,000 Hz, and (i) $8000 \mathrm{~Hz}$. (B) Effect of frequency on real surface area of nanostructure gold electrode by integration of the reduction peak of cyclic voltammograms in a solution of $0.5 \mathrm{M}$ sulfuric acid at a scan rate of $100 \mathrm{mV} / \mathrm{second}\left(\mathrm{R}=\mathrm{A}_{\text {nanostructure gold }} / \mathrm{A}_{\text {planar gold electrode }}\right)$. (C) Scanning electron microscopic image of the planar gold electrode and (D) after pretreatment of square-wave oxidation reduction cycle at $8000 \mathrm{~Hz}$ for 5 minutes. Abbreviations: $\mathrm{Ag}$, silver; $\mathrm{AgCl}$, silver chloride; freq, frequency; vs, versus.

A

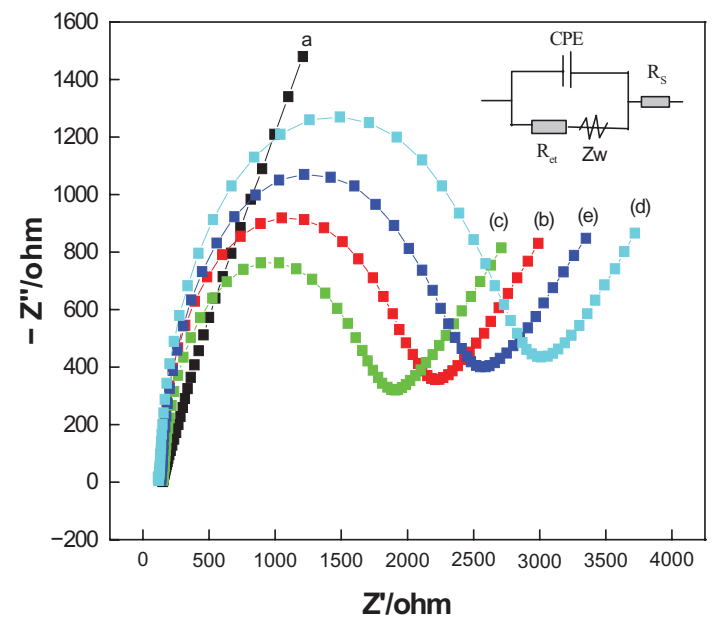

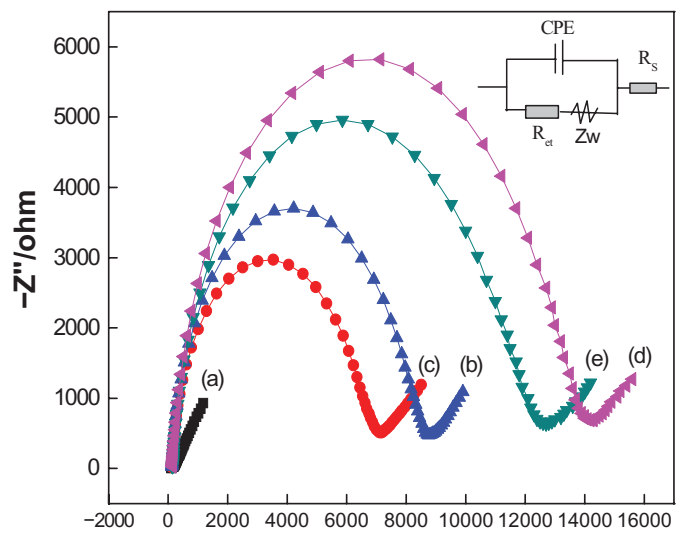

Z'ohm

Figure 3 Impedance spectra (Nyquist plots) corresponding to (A) nanostructure gold electrode and (B) planar gold electrode. (a) Bare electrode, (b) after immobilization of capture probe, (c) after accumulation of hexaamine-ruthenium III to the single-stranded deoxyribonucleic acid, (d) hybridization with target deoxyribonucleic acid, and (e) after accumulation of hexaamine-ruthenium III to the double-stranded deoxyribonucleic acid.

Notes: Data were recorded in the presence of $10 \mathrm{mM}$ iron-hexacyano complexes, $\left[\mathrm{Fe}(\mathrm{CN})_{6}\right]^{3-14}$, as redox label. Biased potential was $0.08 \mathrm{~V}$ (versus silver/silver chloride) in the frequency range of $0.05-10^{5} \mathrm{~Hz}$ and amplitude was $5.0 \mathrm{mV}$.

Abbreviation: $\mathrm{R}_{\mathrm{et}}$, electrotransfer resistance. 
iron-hexacyano complexes. $\mathrm{R}_{\mathrm{et}}$ decreased from $1862 \Omega$ to $1547 \Omega$ after the accumulation of RuHex onto the probe. The decrease in $\mathrm{R}_{\mathrm{et}}$ was due to accumulation of positivelycharged RuHex on the electrode surface, resulting in partial neutralization of the negative charges which promoted the ability of the redox probe to access the electrode surface. Subsequently, the target DNA was hybridized with the probe to form dsDNA and the value of $\mathrm{R}_{\mathrm{et}}$ increased to $2573 \Omega$ due to the large amount of negatively-charged DNA linked on the electrode surface. After accumulation of RuHex onto dsDNA, $\mathrm{R}_{\mathrm{et}}$ decreased from $2573 \Omega$ to $2179 \Omega$ due to positivelycharged RuHex bound to phosphates. For the planar gold electrode, $\mathrm{R}_{\mathrm{et}}$ in each modification step increased sharply compared with corresponding step for the NSG electrode, which indicated that the NSG electrode possessed high conductivity due to its nanostructure architecture.

\section{Electrochemical response of RuHex-bound probe}

Detection of hybridization was accomplished by using RuHex as the signaling molecule. Previous studies demonstrated that RuHex could bind to DNA by electrostatic interaction since the DNA backbone has a negative charge. ${ }^{44}$ Cyclic voltammetry was first employed to characterize the electrochemistry of RuHex at NSG electrode surfaces with DNA/ $\mathrm{MCH}$ monolayers. As shown in Figure 4A, a pair of peaks corresponding to the reduction and oxidation of RuHex could

A

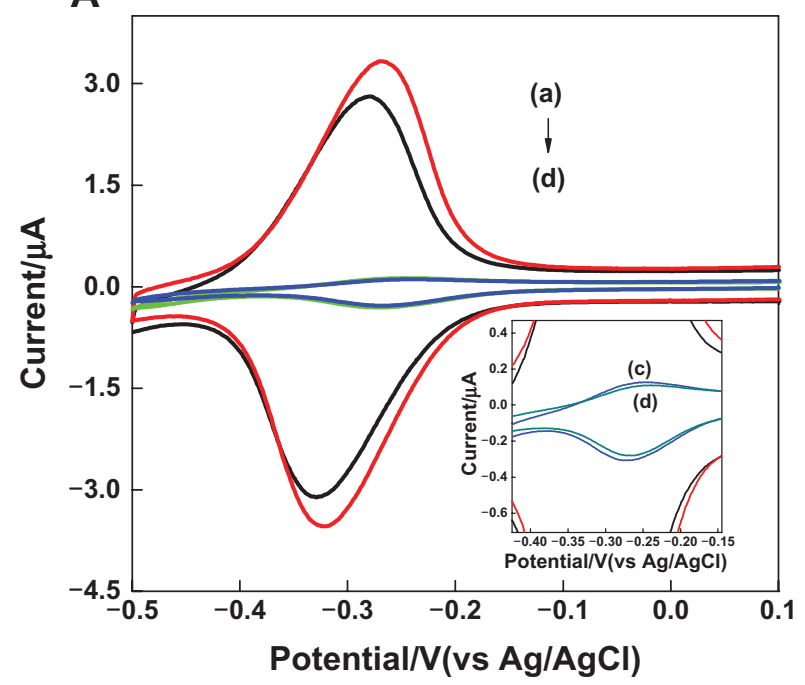

be observed at $10 \mathrm{mM}$ tris- $\mathrm{HCl}$ containing $20 \mu \mathrm{M}$ RuHex (Figure 4A, curve b), indicating that the electron transfer reaction of RuHex at the DNA/MCH surface was a surfaceconfined redox process since the peak currents were linearly proportional to scan rates. This pair of peaks was ascribed to RuHex electrostatically binding to the DNA surface and reflected the amount of DNA on the NSG electrode surface. ${ }^{49}$ After hybridization of the immobilized probes with the complementary DNA sequence, the amount of RuHex electrostatically binding to the NSG electrode surface increased and finally resulted in much higher current signals (Figure 4A, curve a). Cyclic voltammograms of the planar gold electrode before and after hybridization are shown in Figure 4A, curves c and d. Results indicate that the current signals of the NSG electrode were much higher than that of the planar, which could be explained by the amount immobilized on the NSG electrode increasing due to the large real surface area.

Previous studies demonstrated that the RuHex/DNA/ electrode system generated significantly more intense signal in chronocoulometry than in voltammetry. ${ }^{50,51}$ Chronocoulometry was then carried out to characterize the redox process of RuHex. Charges of RuHex were measured before and after hybridization with the target DNA (Figure 4B). A significant increase of charges was observed after hybridization with $10 \mathrm{nM}$ target DNA due to the increase of RuHex bound onto the NSG electrode surface (Figure 4B, curves a and b). Thus, the increase of charges

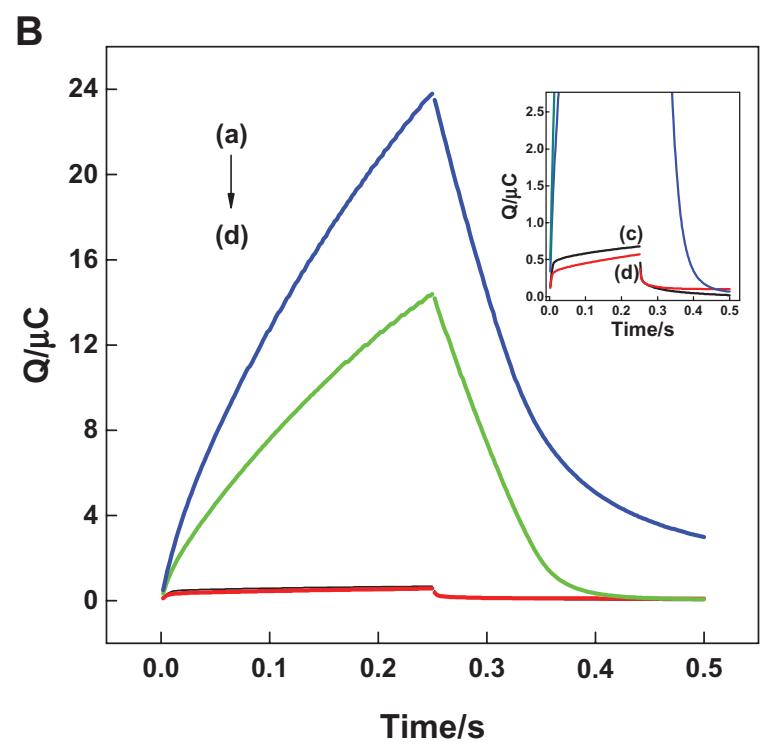

Figure 4 (A) Cyclic voltammograms and (B) chronocoulometry curves for $20 \mu \mathrm{M}$ hexaamine-ruthenium III as redox indicator at (a) double-stranded deoxyribonucleic acid modified nanostructure gold electrode, (b) single-stranded deoxyribonucleic acid modified nanostructure gold electrode, (c) double-stranded deoxyribonucleic acid modified planar gold electrode, and (d) single-stranded deoxyribonucleic acid modified planar gold electrode. Electrolyte was $10.0 \mathrm{mM}$ tris buffer ( $\mathrm{pH} 7.4$ ) containing $20 \mu \mathrm{M}$ hexaamineruthenium III.

Note: Scan rate $=50 \mathrm{mV} /$ second, pulse period $=250$ milliseconds.

Abbreviations: $\mathrm{Ag}$, silver; $\mathrm{AgCl}$, silver chloride; s, seconds; vs, versus. 
reflected the extent of hybrid formation. For comparison, chronocoulometry of a planar gold electrode-based biosensor with the same target concentrations was also investigated (Figure 4B, curves $\mathrm{c}$ and $\mathrm{d}$ ). The increment of charges observed on the NSG electrode was about 60 times higher than that of the planar gold electrode, which demonstrated that the NSG-based biosensor greatly increased the efficiency of hybridization.

\section{Selectivity of electrochemical DNA biosensor}

Figure 5A showed the chronocoulometry curves of the DNA-modified NSG electrodes measured in blank tris$\mathrm{HCl}$ buffer solution after immersion in $20 \mu \mathrm{M}$ RuHex of $10 \mathrm{mM}$ tris- $\mathrm{HCl}(\mathrm{pH} \mathrm{7.4)}$ for 30 minutes. It was clear that the lowest charges were obtained on the ssDNA-modified
NSG electrode (Figure 5A, curve d). A significant increase of charges was observed after hybridization with complementary target DNA (Figure 5A, curve a), which indicated that the probe had completely hybridized with complementary DNA. In the presence of single-base mismatched DNA, the redox charges of RuHex (Figure 5A, curve b) significantly decreased compared with complementary DNA, showing that hybridization of the capture probe with single-base mismatched DNA was incomplete. Moreover, almost the same redox charges were obtained when the sole capture probe was hybridized with noncomplementary target DNA (Figure 5A, curve c), demonstrating that no successful hybridization occurred due to sequence mismatch. Chronocoulometric response curves were converted to Anson plots by plotting charge versus half-life (Figure 5B). The linear part of the Anson plot was then extrapolated back to
A

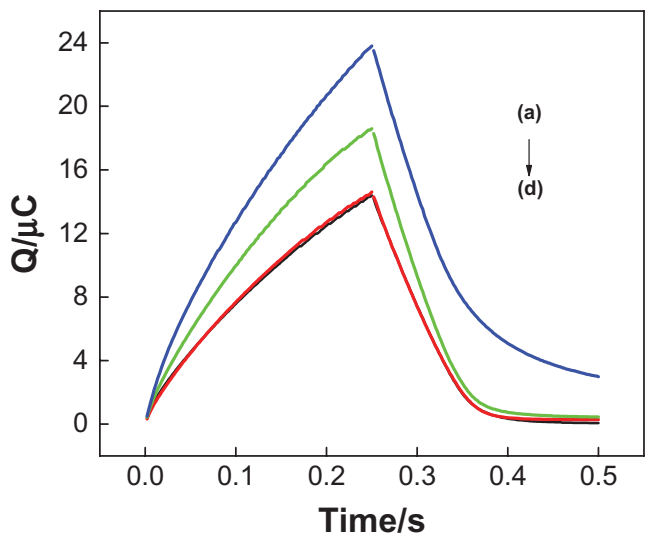

C

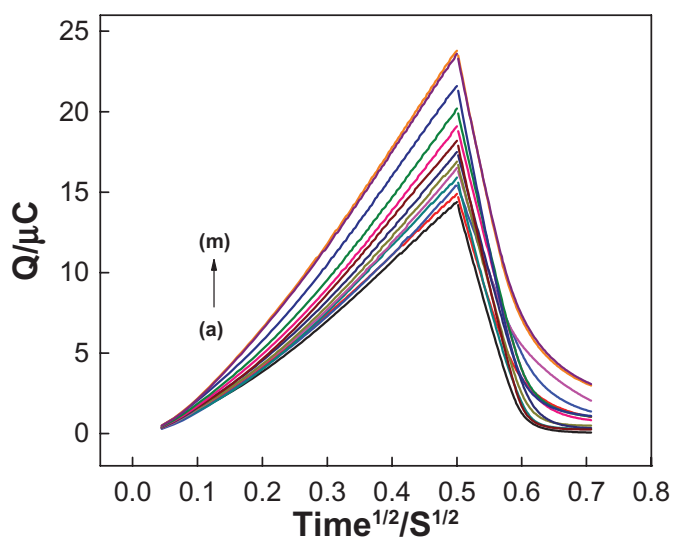

B

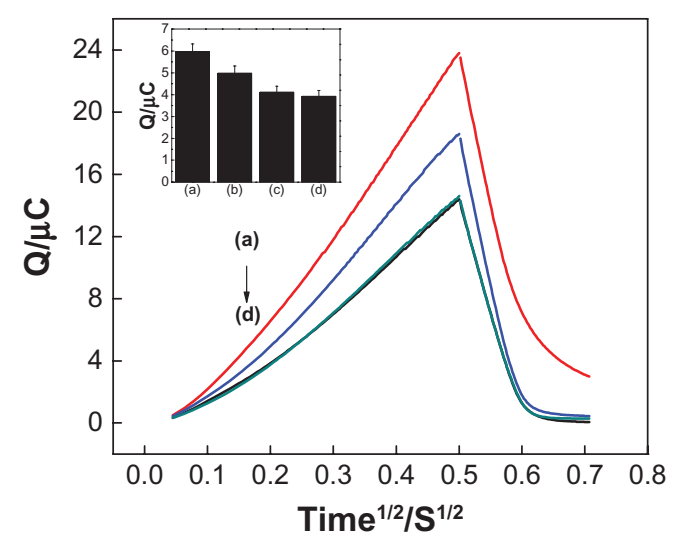

D

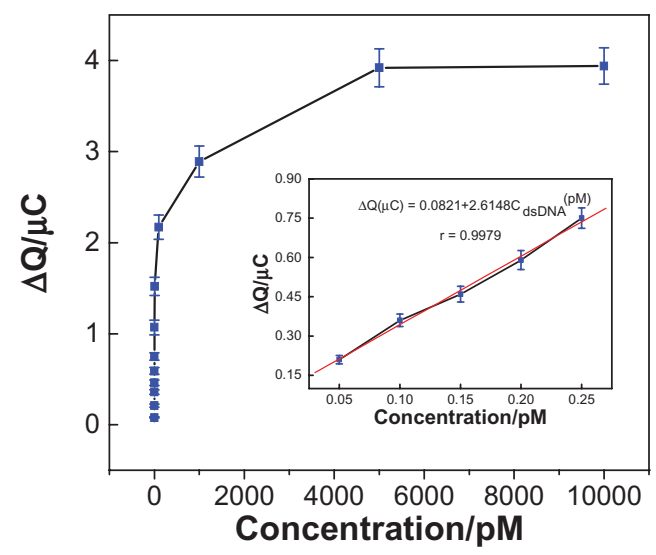

Figure 5 (A) Chronocoulometry curves using $20 \mu \mathrm{M}$ hexaamine-ruthenium III as redox indicator for (d) probe-modified nanostructure gold electrode, and after hybridization with (a) complementary target sequence, (b) single-base mismatch sequence, and (c) noncomplementary sequence. (B) Chronocoulometry transients of hexaamineruthenium III for (d) probe-modified nanostructure gold electrode, and after hybridization with (a) complementary target sequence, (b) single-base mismatch sequence, and (c) noncomplementary sequence. (C) Chronocoulometry transients for nanostructure gold electrodes with capture probe hybridized with target DNA at a series of concentrations: (a) 0 M, (b) 20 fM, (c) 50 fM, (d) 100 fM, (e) 150 fM, (f) 200 fM, (g) 250 fM, (h) IpM, (i) 10 pM, (j) 100 pM, (k) I nM, (I) 5 nM, and (m) I0 nM. (D) Calibration curve of the deoxyribonucleic acid sensor, where the definition of signal is the same as that in Figure $5 \mathrm{C}$. Inset shows the plot of the charge increment of hexaamineruthenium III as a function of the target concentration. Concentration of target deoxyribonucleic acid was $50 \mathrm{fM}, 100 \mathrm{fM}, 150 \mathrm{fM}, 200 \mathrm{fM}$, and $250 \mathrm{fM}$.

Notes: Error bars represent relative standard deviation of three independent experiments. Other experimental conditions are as described in Figure 4.

Abbreviation: s, seconds. 
time zero to obtain the intercept of the plot for ssDNA and hybridization with complementary target DNA, single-base mismatched DNA, and noncomplementary target DNA. Chronocoulometry experiments showed high selectivity of the constructed DNA biosensor for discriminating complementary DNA from single-base mismatched DNA and noncomplementary DNA.

\section{Sensitivity of the NSG-based biosensor}

To further evaluate the detection performance of the NSGbased biosensor, the charges of RuHex were measured after hybridization with target DNA at different concentrations. Figure $5 \mathrm{C}$ and $\mathrm{D}$ show that the charges of RuHex on the NSG electrode increased with increasing target DNA concentration (ranging from $20 \mathrm{fM}$ to $5 \mathrm{nM}$ ) and then tended to remain constant, indicating that all available immobilized probes on the NSG electrode surface were involved in hybridization. Inset shows that the increment of charges was related to target concentrations across the range of $50 \mathrm{fM}$ to $250 \mathrm{fM}$, with the regression equation being $\Delta \mathrm{Q}(\mu \mathrm{C})=0.0821+2.6148$ complementary dsDNA (pM), $\mathrm{R}=0.9979$. The detection limit was estimated to be $5.6 \mathrm{fM}$ by using $3 \sigma$ (where $\sigma$ is the standard deviation of the blank solution, $n=3$ ). The reproducibility of the biosensor for detection of $0.15 \mathrm{pM}$ target DNA was $7.32 \%(n=3)$. The NSG-based biosensor possessed good molecular recognizability and could hybrid with completely complementary sequences well. Thus, this biosensor was used for detection of PCR amplified real samples.

\section{Detection of electrophoresis and electrochemistry of PCR products}

All PCR samples were obtained from the First Affiliated Hospital of Fujian Medical University (Fujian, China). The positive real sample, which came from an osteosarcoma patient, contained PCR product that had a sequence complementary to the specific survivin probe. The PCR product from a negative real sample, which came from a normal person, contained a sequence noncomplementary to the specific survivin probe. As the blank background, the PCR buffer system didn't contain any DNA templates. Figure 6A shows the result of electrophoresis of PCR products. PCR amplification products from positive real samples (Figure 6A, lane 2) show the light brands in $1.5 \%$ agarose gel. However, PCR products from negative real samples (Figure 6A, lane 1) and blank background (Figure 6A, lane 3 ) did not present any light brands in the gel.

Figure 6B shows the chronocoulometry curves of RuHex when the capture probe was immobilized and different real samples were used in the hybridization step. The charges of RuHex obtained from the probe-modified NSG-based biosensor gave a mean average of $3.765 \mu \mathrm{C}$ with a relative standard deviation (RSD) of $7.36 \%$. Blank background was measured

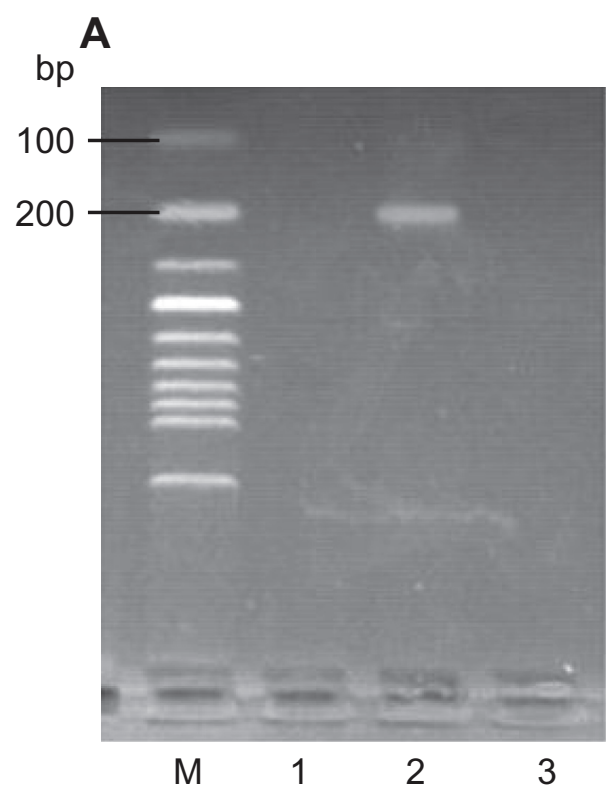

B

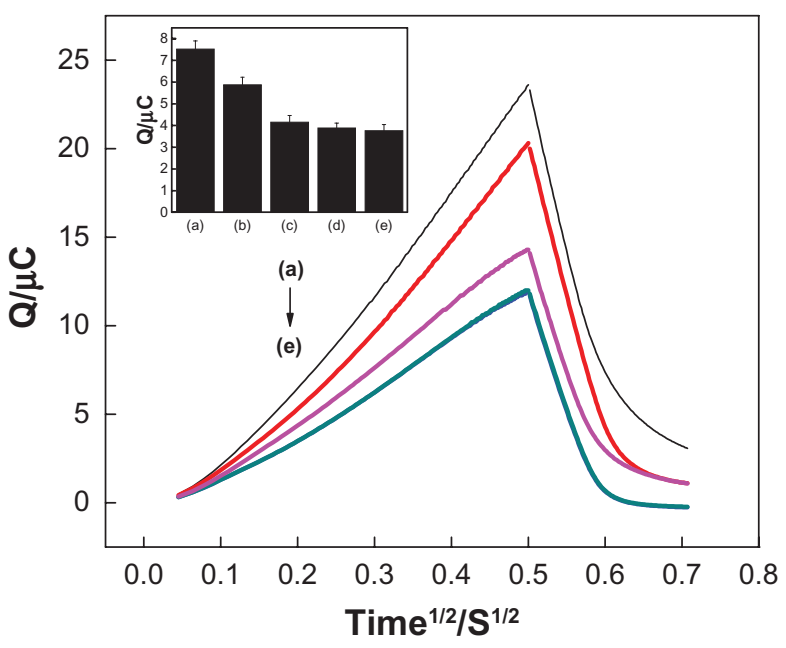

Figure 6 (A) Electropherogram of polymerase chain reaction products. The lanes from left to right: (1) negative real sample, (2) positive real sample, and (3) blank background. (B) Chronocoulometry transients using $20 \mu \mathrm{M}$ hexaamine-ruthenium III as redox indicator for (e) probe-modified nanostructure gold electrode, (c) blank background, (b) after hybridization with the positive sample, (d) negative sample, and (a) the same concentration of target deoxyribonucleic acid.

Notes: Error bars represent relative standard deviation of three independent experiments. Experimental conditions are as described in Figure 4. 
and the signals gave a mean average of $4.151 \mu \mathrm{C}$ with an RSD of $7.59 \%$. The charges of RuHex obtained from hybridization of the probe with positive and negative real samples gave a mean average of $5.879 \mu \mathrm{C}$ with an RSD of $5.96 \%$ and 3.886 $\mu \mathrm{C}$ with an RSD of $6.15 \%$, respectively. The charges obtained from hybridization of the probe with the same concentration of target DNA gave a mean average of $7.52 \mu \mathrm{C}$ with an RSD of $5.35 \%$. The signal of RuHex obtained from hybridization of the probe with positive real samples (Figure 6B, curve b) was much higher than that of the probe-modified NSG electrode (Figure 6B, curve e), indicating that hybridization at the NSG electrode surface occurred and the amount of RuHex bound with the hybrid increased. When the capture probe was hybridized with negative real samples which did not contain a target sequence, the signal of RuHex was almost the same as the probe-modified NSG electrode (Figure 6B, curves d and e), demonstrating that hybridization had not occurred due to sequence mismatch. Furthermore, the electrochemical signal obtained from hybridization of the probe with target DNA was higher than that of the same concentration of positive real samples, indicating that hybridization efficiency could be affected by the size of DNA fragment due to steric hindrance. Results showed that the electrochemical DNA biosensor was in good agreement with those obtained from gel electrophoresis.

\section{Conclusion}

A novel electrochemical DNA biosensor based on a nanostructure electrode was constructed for detection of survivin gene by using RuHex as an electrochemical indicator. Preparation of the nanostructure electrode was quite simple, economical, and controllable. Due to the large active surface, the NSG electrode possessed superior conductivity, activity, and biocompatibility. With the use of RuHex as an indicator, the optimized DNA biosensor could detect the target DNA at a concentration as low as $5.6 \mathrm{fM}$. The current fabricated biosensor was used for assay of the complementary sequence in PCR amplified real samples with satisfactory results. Moreover, this electrode modification strategy is expected to have further extensive applications in protein and enzyme biosensors.

\section{Acknowledgments}

The authors gratefully acknowledge the financial support of National High Technology and Development of China (863 Project: 2008AA02Z433), National Natural Science Foundation of China (20805006, 20975021, 81171668),
Fujian Provincial University-Industry Cooperation Science and Technology Major Program (2010Y4003), Foundation of Fujian Key Laboratory of Hematology (2009J1004), Scientific Research Major Program of Fujian Medical University (09ZD013), Natural Science Foundation of Fujian Province of China (2010J06011), and Foundation of Fujian Provincial Department of Education (JA10126, JA11110).

\section{Disclosure}

The authors report no conflicts of interest in this work.

\section{References}

1. Bielack SS, Kempf-Bielack B, Delling G, et al. Prognostic factors in high-grade osteosarcoma of the extremities or trunk: an analysis of 1,702 patients treated on neoadjuvant cooperative osteosarcoma study group protocols. J Clin Oncol. 2002;20(3):776-790.

2. Osaka E, Suzuki T, Osaka S, et al. Survivin as a prognostic factor for osteosarcoma patients. Acta Histochem Cytochem. 2006;39(3):95-100.

3. Trieb K, Lehner R, Stulnig T, Sulzbacher I, Shroyer KR. Survivin expression in human osteosarcoma is a marker for survival. Eur J Surg Oncol. 2003;29(4):379-382.

4. Verdicia MA, Huang H, Dutil E, Kaiser DA, Hunter T, Noel JP Structure of human anti-apoptotic protein survivin reveals a dimeric arrangement. Nat Struct Biol. 2000;7(7):602-608.

5. Chantalat L, Skoufias, DA, Kleman JP, Jung B, Dideberg O, Margolis RL. Crystal structure of survivin reveals a bow tie-shaped dimmer with two unusual alpha-helical extensions. Mol Cell. 2000;6(1): 183-189.

6. Ambrosini G, Adida C, Altieri DC. A novel anti-apoptotic gene, survivin, expressed in cancer and lymphoma. Nat Med. 1997;3(8):917-921.

7. Lu CD, Altieri DC, Tanigawa N. Expression of a novel antiapoptosis gene, survivin, correlated with tumor cell apoptosis and p53 accumulation in gastric carcinomas. Cancer Res. 1998;58(9):1808-1812.

8. Zaffaroni N, Pennati M, Collela G, et al. Expression of anti-apoptotic gene survivin correlates with taxol resistance in human ovarian cancer. Cell Mol Life Sci. 2002;59(8):1406-1412.

9. Rodel C, Hass J, Groth A, Grabenbauer GG, Sauer R, Rödel F. Spontaneous and radiation-induced apoptosis in colorectal carcinoma cells with different intrinsic radiosensitivities: survivin as a radioresistance factor. Int J Radiat Oncol Biol Phys. 2003;55(5):1341-1347.

10. Taran J, Master Z, Yu JI, Rak J, Dumont DJ, Kerbel RS. A role of survivin in chemoresistance of endothelial cells mediated by VEGF. Proc Natl Acad Sci US A. 2002;99(7):4349-4354.

11. Sah NK, Khan Z, Khan GJ, Bisen PS. Structural, functional and therapeutic biology of survivin. Cancer Lett. 2006;244(2):164-171.

12. Yamamoto T, Tanigawa N. The role of survivin as a new target of diagnosis and treatment in human cancer. Med Electron Microsc. 2001;34(4):207-212.

13. Altieri DC. The molecular basis and potential role of survivin in cancer diagnosis and therapy. Trends Mol Med. 2001;7(12):542-547.

14. Li FZ, Altieri DC. The cancer antiapoptosis mouse survivin gene: characterization of locus and transcriptional requirements of basal and cell cycle-dependent expression. Cancer Res. 1999;59(13):3143-3151.

15. Conway EM, Pollefeyt S, Cornelissen J, et al. Three differentially expressed survivin cDNA variants encode proteins with distinct antiapoptotic functions. Blood. 2000;95(4):1435-1442.

16. Choi KS, Lee TH, Jung MH. Ribozyme-mediated cleavage of the human survivin mRNA and inhibition of antiapoptotic function of survivin in MCF-7 cells. Cancer Gene Ther. 2003;10(2):87-95.

17. Falleni M, Pellegrini C, Marchetti A, et al. Survivin gene expression in early-stage non-small cell lung cancer. J Pathol. 2003;200(5):620-626. 
18. Bagni G, Osella D, Sturchio E, Mascini M. Deoxyribonucleic acid (DNA) biosensors for environmental risk assessment and drug studies. Anal Chim Acta. 2006;573-574:81-89.

19. Tsai JJ, Bau IJ, Chen HT, Lin YT, Wang GJ. A novel nanostructured biosensor for the detection of the dust mite antigen Der p2. Int $J$ Nanomedicine. 2011;6:1201-1208.

20. Zhou W, Ma Y, Yang H, Ding Y, Luo X. A label-free biosensor based on silver nanoparticles array for clinical detection of serum p53 in head and neck squamous cell carcinoma. Int J Nanomedicine. 2011;6:381-386.

21. Liu Q, Liu A, Gao F, et al. Coupling technique of random amplified polymorphic DNA and nanoelectrochemical sensor for mapping pancreatic cancer genetic fingerprint. Int J Nanomedicine. 2011;6:2933-2939.

22. Hahm J, Lieber CM. Direct ultrasensitive electrical detection of DNA and DNA sequence variations using nanowire nanosensors. Nano Lett. 2004;4(1):51-54.

23. Wang J, Liu G, Merkoci A. Electrochemical coding technology for simultaneous detection of multiple DNA targets. J Am Chem Soc. 2003;125(11):3214-3215.

24. Chang H, Yuan Y, Shi N, Guan Y. Electrochemical DNA biosensor based on conducting polyaniline nanotube array. Anal Chem. 2007;79(13):5111-5115.

25. Zhang J, Song SP, Zhang LY, et al. Sequence-specific detection of femtomolar DNA via a chronocoulometric DNA sensor (CDS): effects of nanoparticle-mediated amplification and nanoscale control of DNA assembly at electrodes. J Am Chem Soc. 2006;128(26):8575-8580.

26. Qiu H, Xue L, Ji G, et al. Enzyme-modified nanoporous gold-based electrochemical biosensors. Biosens Bioelectron. 2009;24(10):3014-3018.

27. Wei Q, Zhao Y, Xu C, et al. Nanoporous gold film based immunosensor for label-free detection of cancer biomarker. Biosens Bioelectron. 2011;26(8):3714-3718.

28. Shin HC, Dong J, Liu M. Nanoporous structures prepared by an electrochemical deposition process. Adv Mater. 2003;15(19):1610-1614.

29. Li F, Han X, Liu S. Development of an electrochemical DNA biosensor with a high sensitivity of $\mathrm{fM}$ by dendritic gold nanostructure modified electrode. Biosens Bioelectron. 2011;26(5):2619-2625.

30. Deng Y, Huang W, Chen X, Li Z. Facile fabrication of nanoporous gold film electrodes. Electrochem Commun. 2008;10(5):810-813.

31. Zhao W, Xu JJ, Shi CG, Chen HY. Fabrication, characterization and application of gold nano-structured film. Electrochem Commun. 2006;8(5):773-778.

32. Zielasek V, Jürgens B, Schulz C, et al. Gold catalysts: nanoporous gold foams. Angew Chem Int Ed Engl. 2006;45(48):8241-8244.

33. Mortari A, Maaroof A, Martin D, Cortie MB. Mesoporous gold electrodes for sensors based on electrochemical double layer capacitance. Sens Actuators B Chem. 2007;123(1):262-268.

34. Lang XY, Guo H, Chen LY, et al. Novel nanoporous Au-Pd alloy with high catalytic activity and excellent electrochemical stability. J Phys Chem C. 2010;114(6):2600-2603.

35. Yu C, Jia F, Ai Z, Zhang L. Direct oxidation of methanol on selfsupported nanoporous gold film electrodes with high catalytic activity and stability. Chem Mater. 2007;19(25):6065-6067.
36. Huang JF, Sun IW. Fabrication and surface functionalization of nanoporous gold by electrochemical alloying/dealloying of $\mathrm{Au}-\mathrm{Zn}$ in an ionic liquid, and the self-assembly of L-cysteine monolayers. $A d v$ Funct Mater. 2005;15(6):989-994.

37. Jia F, Yu C, Ai Z, Zhang L. Fabrication of nanoporous gold film electrodes with ultrahigh surface area and electrochemical activity. Chem Mater. 2007;19(15):3648-3653.

38. Bartlett PN, Baumberg JJ, Birkin PR, Ghanem MA, Netti MC. Highly ordered macroporous gold and platinum films formed by electrochemical deposition through templates assembled from submicron diameter monodisperse polystyrene spheres. Chem Mater. 2002;14(5):2199-2208.

39. Gao W, Xia XH, Xu JJ, Chen HY. Three-dimensionally ordered macroporous gold structure as an efficient matrix for solid-state electrochemiluminescence of $\mathrm{Ru}(\mathrm{bpy})_{3}{ }^{2+} / \mathrm{TPA}$ system with high sensitivity. J Phys Chem C. 2007;111(13):12213-12219.

40. Li Y, Song YY, Yang C, Xia XH. Hydrogen bubble dynamic template synthesis of porous gold for nonenzymatic electrochemical detection of glucose. Electrochem Commun. 2007;9(5):981-988.

41. Bilmes SA, Rubim JC, Otto AJ. SERS from pyridine adsorbed on electrodispersed platinum electrodes. Chem Phys Lett. 1989;159(1):89-96.

42. Gamero M, Pariente F, Lorenzo E, Alonso C. Nanostructured rough gold electrodes for the development of lactate oxidase-based biosensors. Biosens Bioelectron. 2010;25(9):2038-2044.

43. Zhong G, Liu A, Chen X, et al. Electrochemical biosensor based on nanoporous gold electrode for detection of PML/RAR $\alpha$ fusion gene. Biosens Bioelectron. 2011;26(9):3812-3817.

44. Steel AB, Herne TM, Tarlov MJ. Electrochemical quantitation of DNA immobilized on gold. Anal Chem. 1998;70(22):4670-4677.

45. Fan C, Plaxco KW, Heeger AJ. Electrochemical interrogation of conformational changes as a reagentless method for the sequence-specific detection of DNA. Proc Nat Acad Sci U S A. 2003;100(16):9134-9137.

46. Arinaga K, Rant U, Tornow M, Fujita S, Abstreiter G, Yokoyama N. The role of surface charging during the coadsorption of mercaptohexanol to DNA layers on gold: direct observation of desorption and layer reorientation. Langmuir. 2006;22(13):5560-5562.

47. Lin XH, Wu P, Chen W, Zhang YF, Xia XH. Electrochemical DNA biosensor for the detection of short DNA species of chronic myelogenous leukemia by using methylene blue. Talanta. 2007;72(2):468-471.

48. Hu K, Lan D, Li X, Zhang S. Electrochemical DNA biosensor based on nanoporous gold electrode and multifunctional encoded DNA-Au bio bar codes. Anal Chem. 2008;80(23):9124-9130.

49. Ho PS, Frederick CA, Saal D, Wang AH, Rich A. The interactions of ruthenium hexaamine with Z-DNA: crystal structure of a $\mathrm{Ru}\left(\mathrm{NH}_{3}\right)_{6}{ }^{3+}$ salt of d(CGCGCG) at 1.2A resolution. J Biomol Struct Dyn. 1987;4(4): 521-534.

50. Lao R, Song S, Wu H, et al. Electrochemical interrogation of DNA monolayers on gold surfaces. Anal Chem. 2005;77(19):6475-6480.

51. Katz E, Weizmann Y, Willner I. Magnetoswitchable reactions of DNA monolayers on electrodes: gating the processes by hydrophobic magnetic nanoparticles. J Am Chem Soc. 2005;127(25):9191-9200.
International Journal of Nanomedicine

\section{Publish your work in this journal}

The International Journal of Nanomedicine is an international, peerreviewed journal focusing on the application of nanotechnology in diagnostics, therapeutics, and drug delivery systems throughout the biomedical field. This journal is indexed on PubMed Central, MedLine, CAS, SciSearch ${ }^{\circledR}$, Current Contents $₫ /$ Clinical Medicine,

\section{Dovepress}

Journal Citation Reports/Science Edition, EMBase, Scopus and the Elsevier Bibliographic databases. The manuscript management system is completely online and includes a very quick and fair peer-review system, which is all easy to use. Visit http://www.dovepress.com/ testimonials.php to read real quotes from published authors. 